\title{
STRATEGI PEMBELAJARAN BAHASA INDONESIA (Pengantar Kajian Pembelajara Efektif)
}

\author{
Oleh \\ Martono
}

\begin{abstract}
Abstrak: Pendidikan bertujuan untuk mengembangkan potensi peserta didik agar menjadi manusia yang beriman dan bertakwa kepada Tuhan Yang Maha Esa, berahlak mulia, sehat, berilmu, cakap, kreatif, mandiri, dan menjadi warga negara yang demokratis serta bertanggung jawab. Pendidikan harus menyentuh potensi nurani maupun potensi kompetensi peserta didik. Efisiensi dan keefektifan mengajar dalam proses interaksi belajar yang baik adalah segala daya upaya guru untuk membantu para siswa agar bisa belajar dengan baik. Satu diantara perubahan paradigma pembelajaran tersebut adalah orientasi pembelajaran yang semula berpusat pada guru beralih berpusat pada murid.Metode yang semula lebih didominasi ekspositoriberganti ke partisipatori,dan pendekatan yang semula lebih banyak bersifat tekstualberubah menjadi kontekstual. Semua perubahan tersebut dimaksudkan untuk memperbaiki mutu pendidikan, baik dari segi proses maupun hasil pendidikan. Untuk mengetahui keefektifan pembelajaran Bahasa Indonesia dengan memberikan tes, sebab hasil tes dapat dipakai untuk mengevaluasi berbagai aspek proses pengajaran.
\end{abstract}

Kata kunci: strategi, belajar, pembelajaran

Abstract: Education aims to develop the potential of learners to become human beings who believe and cautious to God Almighty, noble, healthy, knowledgeable, capable, creative, independent, and become citizens of a democratic and responsible. Education must touch the potential of conscience and the potential competence of learners. Efficiency and effectiveness of teaching in good learning interaction are all teachers' efforts to help students learn well. One of the changes in the learning paradigm is the learning orientation that originally centered on teachers switching to student-centered. The former dominated

${ }^{1}$ Martono adalah dosen Program Studi Pendidikan Bahasa Indonesia FKIP UNTAN 
expository method changed to participatory, and the more textual approaches became contextual. All changes are intended to improve the quality of education, both in terms of process and educational outcomes. To know the effectiveness of learning Indonesian by giving the test, because the test results can be used to evaluate various aspects of the teaching process.

Keywords: strategy, learning

\section{Pendahuluan}

Undang-Undang Nomor 20 Tahun 2003 tentang Sistem Pendidikan Nasional menyebutkan, bahwa pendidikan nasional berfungsi mengembangkan kemampuan dan membentuk watak serta peradaban bangsa yang bermartabat dalam rangka mencerdaskan kehidupan bangsa. Pendidikan bertujuan untuk mengembangkan potensi peserta didik agar menjadi manusia yang beriman dan bertakwa kepada Tuhan Yang Maha Esa, berahlak mulia, sehat, berilmu, cakap, kreatif, mandiri, dan menjadi warga negara yang demokratis serta bertanggung jawab.

Pendidikan yang mampu mendukung pembangunan di masa mendatang adalah pendidikan yang mampu mengembangkan potensi peserta didik, sehingga yang bersangkutan mampu menghadapi dan memecahkan problema kehidupan yang dihadapinya. Pendidikan harus menyentuh potensi nurani maupun potensi kompetensi peserta didik. Konsep pendidikan tersebut terasa semakin penting ketika seseorang harus memasuki kehidupan di masyarakat dan dunia kerja, karena yang bersangkutan harus mampu menerapkan apa yang dipelajari di sekolah untuk menghadapi problema yang dihadapi dalam kehidupan sehari-hari saat ini maupun yang akan datang.

Masalah utama dalam pembelajaran pada pendidikan formal dewasa ini adalah masih rendahnya daya serap peserta didik. Hal ini tampak dari rerata hasil belajar peserta didik yang senantiasa masih sangat memprihatinkan. Prestasi ini tentunya merupakan hasil kondisi pembelajaran yang masih bersifat konvensional dan tidak menyentuh ranah dimensi peserta didik itu sendiri, yaitu bagaimana sebenarnya belajar itu (belajar untuk belajar). Dalam arti yang lebih substansial, bahwa proses pembelajaran hingga dewasa ini masih memberikan dominasi guru dan tidak memberikan akses bagi anak didik untuk berkembang secara mandiri melalui penemuan dalam proses berpikirnya.

Pendidikan yang baik adalah pendidikan yang tidak hanya mempersiapkan para siswanya untuk sesuatu profesi atau jabatan, tetapi untuk menyelesaikan masalah-masalah yang dihadapinya dalam kehidupan seharihari. Siswa merupakan subyek didik yang memiliki tingkah laku. Untuk 
memahami tingkah laku siswa secara tuntas, diperlukan pemahaman terhadap respons itu sendiri, dan berbagai konsekuensi yang diakibatkan oleh respon tersebut.

Dalam kurikulum 2013 menuntut perubahan paradigma dalam pendidikan dan pembelajaran, khususnya di lembaga pendidikan formal (persekolahan). Perubahan tersebut harus pula diikuti oleh guru yang bertanggung jawab atas penyelenggaraan pembelajaran di sekolah (di dalam kelas ataupun di luar kelas). Satu diantara perubahan paradigma pembelajaran tersebut adalah orientasi pembelajaran yang semula berpusat pada guru (teacher centered) beralih berpusat pada murid (student centered); metode yang semula lebih didominasi ekspositori berganti ke partisipatori; dan pendekatan yang semula lebih banyak bersifat tekstual berubah menjadi kontekstual. Semua perubahan tersebut dimaksudkan untuk memperbaiki mutu pendidikan, baik dari segi proses maupun hasil pendidikan.

\section{Pengertian Belajar}

Menurut Winkel (1996: 53), belajar adalah suatu aktivitas mental/psikis yang berlangsung dalam interaksi aktif dengan lingkungan yang menghasilkan perubahan-perubahan dalam pengetahuan-pemahaman, keterampilan, dan nilai sikap. Perubahan itu bersifat secara relatif konstan dan berbekas. Belajar yang sebaik-baiknya adalah dengan mengalami sesuatu yaitu menggunakan pancaindra. Dengan kata lain, bahwa belajar adalah suatu cara mengamati, membaca, meniru, mengintimasi, mencoba sesuatu, mendengar, dan mengikuti petunjuk tertentu. Belajar itu merupakan perubahan perilaku sebagai hasil dari pengalaman.

Menurut Gagne dinyatakan bahwa belajar merupakan kecenderungan perubahan pada diri manusia yang dapat dipertahankan selama proses pertumbuhan. Hal ini dijelaskan kembali oleh Gagne (1977) bahwa belajar merupakan suatu peristiwa yang terjadi di dalam kondisikondisi tertentu yang dapat diamati, diubah, dan dikontrol. Tingkah laku seseorang berfungsi untuk menjaga kelangsungan hidup, karena di dalam kebutuhan biologis dan pemuasan kebutuhannya menempati posisi sentral. Kebutuhan dikonsepkan sebagai dorongan (drive), seperti lapar, haus, tidur, dan sebagainya. Stimulus hampir selalu dengan kebutuhan biologis ini, meskipun respons mungkin bermacammacam bentuknya.

Respons yang diberikan oleh siswa tidaklah sesederhana itu, sebab pada dasarnya setiap stimulus yang diberikan berinteraksi satu dengan lainnya dan interaksi ini akhirnya memengaruhi respons yang dihasilkan itu. Respons yang diberikan ini juga 
menghasilkan berbagai konsekuensi, yang ada gilirannya akan memengaruhi tingkah laku siswa. Untuk memahami tingkah laku siswa secara tuntas, diperlukan pemahaman terhadap respons itu sendiri, dan berbagai konsekuensi yang diakibatkan olch respons tersebut.

Menurut Degeng (1997: 3) belajar merupakan pengaitan pengetahuan baru pada struktur kognitif yang sudah dimiliki si belajar. Hal ini mempunyai arti bahwa dalam proses belajar, siswa akan menghubung-hubungkan pengetahuan atau ilmu yang telah tersimpan dalam memorinya dan kemudian menghubungkan dengan pengetahuan yang baru. Dengan kata lain, belajar adalah suatu proses untuk mengubah performansi yang tidak terbatas pada keterampilan, tetapi juga meliputi fungsi-fungsi, seperti skill, persepsi, emosi, proses berpikir, sehingga dapat menghasilkan perbaikan performansi.

Belajar hakikatnya adalah suatu proses yang ditandai dengan adanya perubahan pada diri seseorang. Perubahan sebagai hasil dari proses belajar dapat diindikasikan dalam berbagai bentuk seperti berubah pengetahuan, pemahaman, sikap dan tingkah laku, kecakapan, keterampilan dan kemampuan, serta perubahan aspek-aspek yang lain yang ada pada individu yang belajar. Dengan demikian, inti dari belajar adalah adanya perubahan tingkah laku karena adanya suatu pengalaman. Perubahan tingkah laku tesebut dapat berupa perubahan keterampilan, kebiasaan, sikap, pengetahuan, pemahaman, dan apresiasi. Adapun pengalaman dalam proses belajar ialah bentuk interaksi antara individu dengan lingkungan. Siswa belajar tak hanya intelektualnya saja, tetapi juga emosional dan jasmaninya. Dalam pengajaran modern guru di samping mengajar, juga mendidik untuk membentuk pribadi siswa.

\section{Pembelajaran}

Dewasa ini, yang kita lihat bahwa sebagian besar pola pembelajaran masih bersifat transmisif, pengajar mentransfer dan menuangkan konsepkonsep secara langsung pada peserta didik. Dalam pandangan ini, siswa secara pasif "menyerap" struktur pengetahuan yang diberikan guru atau yang terdapat dalam buku pelajaran. Pembelajaran hanya sekadar penyampaian fakta, konsep, prinsip, dan keterampilan kepada siswa. Cara ini sangat tidak benar.

Unsur terpenting dalam mengajar ialah merangsang serta mengarahkan siswa belajar. Mengajar pada hakikatnya tidak lebih dari sekadar menolong para siswa untuk memperoleh pengetahuan, keterampilan, sikap, serta ide dan apresiasi yang menjurus kepada perubahan tingkah laku dan pertumbuhan siswa. Cara mengajar guru yang baik merupakan kunci dan prasarat bagi 
siswa untuk dapat belajar dengan baik. Salah satu tolok ukur bahwa siswa telah belajar dengan baik ialah jika siswa itu dapat mempelajari apa yang seharusnya dipelajari, sehingga indikator hasil belajar yang diinginkan dapat dicapai oleh siswa.

Proses belajar terjadi melalui banyak cara baik disengaja maupun tidak disengaja dan berlangsung sepanjang waktu dan menuju pada suatu perubahan pada diri pembelajar. Perubahan yang dimaksud adalah perubahan perilaku tetap berupa pengetahuan, pemahaman, keterampilan, dan kebiasaan yang baru diperoleh individu. Sedangkan pengalaman merupakan interaksi antara individu dengan lingkungan sebagai sumber belajarnya. Jadi, belajar di sini diartikan sebagai proses perubahan perilaku tetap dari belum tahu menjadi tahu, dari tidak paham menjadi paham, dari kurang terampil menjadi lebih terampil, dan dari kebiasaan lama menjadi kebiasaan baru, serta bermanfaat bagi lingkungan maupun individu itu sendiri.

Dalam konteks pembelajaran, sama sekali tidak berarti memperbesar peranan siswa di satu pihak dan memperkecil peranan guru di pihak lain. Dalam istilah pembelajaran, guru tetap harus berperan secara maksimal demikian juga dengan siswa. Perbedaan dimonasi dan aktivitas di atas hanya menunjukkan kepada perbedaan kepada perbedaan tugas-tugas atau perlakuan guru dan siswa terhadap materi dan proses pembelajaran.

Perbedaan peran guru dan siswa dapat dilihat dari metode yang dipilih guru saat menyampaikan materi. Jika guru menentukan proses belajar mengajar dengan menggunakan metode buzz group (diskusi kelompok kecil), yang lebih menekankan kepada aktivitas siswa, maka tidak berarti peran guru semakin kecil. Guru harus tetap berperan secara maksimal agar proses pembelajaran dengan metode ini berlangsung dengan baik.

Efisiensi dan keefektifan mengajar dalam proses interaksi belajar yang baik adalah segala daya upaya guru untuk membantu para siswa agar bisa belajar dengan baik. Untuk mengetahui keefektifan mengajar, dengan memberikan tes, sebab hasil tes dapat dipakai untuk mengevaluasi berbagai aspek proses pengajaran.

Menurut Soemosasmito (dalam Trianto, 2009) suatu pembelajaran dikatakan efektif apabila memenuhi persyaratan utama keefektifan pengajaran, yaitu:

(1) presentasi waktu belajar siswa yang tinggi dicurahkan terhadap KBM;

(2) rata-rata perilaku melaksanakan tugas yang tinggi di antara siswa;

(3) ketetapan antara kandungan materi ajaran dengan kemampuan siswa (orientasi keberhasilan belajar) diutamakan; dan

(4) mengembangkan suasana belajar yang akrab dan positif, mengembangkan struktur kelas yang mendukung butir (2), tanpa 
mengabaikan butir (4).

\section{Strategi Pembelajaran}

Prinsip belajar adalah konsep-konsep ataupun asas (kaidah dasar) yang harus diterapkan di dalam proses belajar mengajar ini mengandung maksud bahwa pendidik akan dapat melaksanakan tugasnya dengan baik apabila guru dapat menerapkan cara mengajar sesuai dengan prinsipprinsip belajar. Diharapkan guru dapat mengontrol sendiri apakah tugastugas mengajar yang dilakukannya telah sesuai dengan prinsip-prinsip belajar. Prinsip-prinsip belajar adalah landasan berpikir, landasan berpijak dan sumber motivasi, dengan harapan tujuan pembelajaran tercapai dan tumbuhnya proses belajar antardidik dan pendidik yang dinamis dan terarah.

Oleh karena itu, guru harus dapat menyusun strategi yang akan digunakan untuk menyampaikan materi. Menurut Dick dan Carey (1990) strategi pembelajaran adalah semua komponen materi/paket pengajaran dan prosedur yang digunakan untuk membantu siswa dalam mencapai tujuan pengajaran. Strategi Pembelajaran tidak hanya terbatas pada prosedur kegiatan, melainkan termasuk seluruh komponen materi atau paket pembelajaran dan pola pembelajaran itu sendiri. Strategi pembelajaran adalah metode dan prosedur yang ditempuh oleh siswa dan guru dalam proses pembelajaran untuk mencapai tujuan instruksional berdasarkan materi pengajaran tertentu dan dengan bantuan unsur penunjang tertentu pula (Hamalik,2003).

Dalam pembelajaran ada istilah pendekatan, metode, dan teknik. Istilah tersebut harus diketahui oleh guru. Menurut Anthony (dalam Syafi'ie, 1992) pendekatan (approach) mengacu pada teori-teori tentang hakikat bahasa dan pembelajaran bahasa yang berfungsi sebagai sumber landasan/prinsip pengajaran bahasa. Pendekatan bersifat aksiomatis, dalam arti bahwa kebenaran teori-teori linguistik dan teori belajar bahasa yang digunakan tidak dipersoalkan lagi. Metode merupakan satu diantara komponen penting dalam kurikulum yang ideal. Istilah metode dalam pengajaran adalah rencana penyajian bahan yang menyeluruh dengan urutan yang sistematis berdasarkan pendekatan tertentu.

Metode bersifat prosedural, dalam arti penerapan suatu metode mesti dikerjakan melalui langkah-langkah yang teratur dan bertahap, dimulai dari penyusunan perencanaan pengajaran, penyajian pelajaran, dan penilaian hasil belajar dan proses belajar-mengajar. metode mengacu pada pengertian yang luas dan pengertian yang sempit. Dalam pengertian yang luas, metode berarti perencanaan secara menyeluruh untuk menyajikan materi pelajaran bahasa secara teratur, bersifat prosedural: meliputi 
penyusunan, penyajian, dan evaluasi pelajaran satuan pelajaran. Sedangkan pengertian metode dalam arti sempit sama dengan teknik mengajar.

Istilah teknik dalam pengajaran mengandung pengertian cara-cara dan alat-alat yang digunakan guru di dalam kelas. Teknik pengajaran berupa berbagai macam cara dan kiat (trich) untuk menyajikan pelajaran dalam rangka mencapai tujuan Standar Kompetensi (SK) dan Kompetensi Dasar (KD). Guru harus lebih dulu mengetahui pendekatan, kemudian menentukan metode yang cocok dengan tujuan pelajaran dan baru memikirkan daya upaya menyampaikan bahan itu kepada murid-murid. Antara pendekatan, metode, dan teknik merupakan suatu sistem yang tidak dapat di pisah-pisahkan.

Dengan memahami beberapa pengertian di atas dapat disimpulkan, bahwa strategi pembelajaran adalah siasat guru dalam mengefektifkan, mengefisienkan, serta mengoptimalkan fungsi dan interaksi antara siswa dengan komponen pembelajaran dalam suatu kegiatan pembelajaran untuk mencapai tujuan pengajaran.

Pada dasarnya strategi pembelajaran mencakup empat hal, yaitu:

1. Penetapan tujuan pembelajaran.

2. Penetapan sistem pendekatan pembelajaran.

3. Pemilihan dan penetapan metode, teknik dan prosedur pembelajaran. Dibagian ini termasuk penetapan alat, media, sumber dan fasilitas pengajaran serta penetapan langkah - langkah strategi pembelajaran.

4. Penetapan kriteria keberhasilan proses pembelajaran dari dan dengan evaluasi yang digunakan.

Ada empat masalah pokok yang sangat penting yang dapat dijadikan pedoman untuk pelaksanaan kegiatan pembelajaran agar berhasil sesuai dengan yang diharapkan, yaitu :

1. Mengidentifikasi dan menetapkan spesifikasi serta kualifikasi perubahan tingkah laku dan kepribadian anak didik sesuai dengan harapan.

2. Memilih pendekatan pembelajaran berdasarkan aspirasi dan pandangan hidup masyarakat pembelajar.

3. Memilih dan menetapkan prosedur, metode, dan teknik pembelajaran yang dianggap paling tepat dan efektif sehingga dapat dijadikan pegangan oleh para guru dalam melaksanakan kegiatan mengajarnya.

4. Menetapkan norma-norma dan batas minimal keberhasilan atau kriteria serta standar keberhasilan, sehingga dapat dijadikan pedoman oleh guru dalam melakukan evaluasi hasil kegiatan belajar mengajar yang selanjutnya akan dijadikan umpan balik untuk 
penyempurnaan sistem instruksional yang bersangkutan secara keseluruhan.

\section{Penutup}

Inti dari belajar adalah adanya perubahan tingkah laku karena adanya suatu pengalaman. Perubahan tingkah laku tesebut dapat berupa perubahan keterampilan, kebiasaan, sikap, pengetahuan, pemahaman, dan apresiasi. Adapun pengalaman dalam proses belajar ialah bentuk interaksi antara individu dengan lingkungan. Sedangkan mengajar pada hakikatnya tidak lebih dari sekadar menolong para siswa untuk memperoleh pengetahuan, keterampilan, sikap, serta ide dan apresiasi yang menjurus kepada perubahan tingkah laku dan pertumbuhan siswa.

Cara mengajar guru yang baik merupakan kunci dan prasyarat bagi siswa untuk dapat belajar dengan baik. Diharapkan guru dapat mengontrol sendiri apakah tugas-tugas mengajar yang dilakukannya telah sesuai dengan prinsip-prinsip belajar. Prinsip-prinsip belajar adalah landasan berpikir, landasan berpijak dan sumber motivasi, dengan harapan tujuan pembelajaran tercapai dan tumbuhnya proses belajar antara siswa dan pendidik yang dinamis dan terarah. Oleh karena itu, guru harus mendisain pembelajaran dengan baik.

\section{Daftar Pustaka}

Degeng, Nyoman Sudana. 1997. Ilmu Pengajaran Taksonomi Variabel. Jakarta: Departemen P \& K Dirjen Dikti. Proyek Pengembangan

Lembaga Pendidikan Tenaga Pendidikan.

Dick Walter dan Lou Carey. 1990. The Systematic Design of Instruction. Amerika: United States

Dimyati dan Mijiono, 2002. Belajar dan Pembelajaran. Jakarta: Rineka Cipta.

Gagne, Robert M. 1977. The Conditions of Learning and Theory of Instuction. Penerjemah. Munandir, Pusat Antaruniversitas untuk Pengembangan dan Peningkatan Aktivitas Instruksional (PAU-PPAI) Universitas Terbuka.

Hamalik, Oemar. 2003. Proses Belajar dan Pembelajaran. Jakarta: PT Bumi Aksara.

Moore, Kenneth D. 2005. Effective Instructional Strategies From Theory to Pactice. California: Thousand Oaks. 
Riyanto, Yatim. Paradigma Baru Pembelajaran: Sebagai Referensi Bagi Guru dan Pendidik dalam Implementasi Pembelajaran yang Efektif dan Berkualitas.Jakarta: Kencana Prenada Media Group.

Slameto. 1995. Belajar dan Faktor-Faktor yang Mempengaruhinya. Jakarta: Bumi Aksara.

Syafi'ie, Imam. 1992. Problematika Pengajaran Bahasa Indonesia di Sekolah Menengah. Bahasa dan Seni, No. 51/Th. XX. Malang. Trianto, 2009. Mendesain Model Pembelajaran Inovatif-Progresif. Konsep, Landasan, dan Implementasinya pada Kurikulum Tingkat Satuan Pendidikan (KTSP). Jakarta: Kencana.

Winkel, W.S. 1996. Psikologi Pengajaran. Jakarta: Garsindo. 